\title{
Novel Concepts of Altered Immunoglobulin G Galactosylation in Autoimmune Diseases
}

\author{
Gillian Dekkers ${ }^{1,2}$, Theo Rispens ${ }^{2}$ and Gestur Vidarsson ${ }^{1 *}$ \\ 'Sanquin Research and Landsteiner Laboratory, Department of Experimental Immunohematology, Academic Medical \\ Centre, University of Amsterdam, Amsterdam, Netherlands, ${ }^{2}$ Sanquin Research and Landsteiner Laboratory, Department of \\ Immunopathology, Academic Medical Centre, University of Amsterdam, Amsterdam, Netherlands
}

OPEN ACCESS

Edited by: Joanna Davies, San Diego Biomedical Research Institute, United States

Reviewed by: Mattias Collin,

Lund University, Sweden Christian Marcel Karsten, University of Lübeck, Germany

Yannic Christoph Bartsch, Universitätsklinikum SchleswigHolstein, Germany

*Correspondence: Gestur Vidarsson g.vidarsson@sanquin.nI

Specialty section:

This article was submitted to Immunological Tolerance and Regulation,

a section of the journal

Frontiers in Immunology

Received: 15 January 2018 Accepted: 05 March 2018

Published: 19 March 2018

Citation:

Dekkers G, Rispens $T$ and Vidarsson G (2018) Novel Concepts

of Altered Immunoglobulin $G$

Galactosylation in Autoimmune

Diseases.

Front. Immunol. 9:553. doi: 10.3389/fimmu.2018.00553
The composition of the conserved N297 glycan in immunoglobulin G (lgG) has been shown to affect antibody effector functions via C1q of the complement system and Fc gamma receptors (FcyR) on immune cells. Changes in the general levels of IgGglycoforms, such as lowered total IgG galactosylation observed in many autoimmune diseases have been associated with elevated disease severity. Agalactosyslated IgG has therefore been regarded and classified by many as pro-inflammatory. However, and somewhat counterintuitively, agalactosylation has been shown by several groups to decrease affinity for $\mathrm{F} c \gamma \mathrm{RIII}$ and decrease $\mathrm{C} 1 \mathrm{q}$ binding and downstream activation, which seems at odds with this proposed pro-inflammatory nature. In this review, we discuss these circumstances where altered lgG galactosylation/glycosylation is found. We propose a novel model based on these observations and current biochemical evidence, where the levels of IgG galactosylation found in the total bulk lgG affect the threshold required to achieve immune activation by autoantibodies through either $\mathrm{C} 1 \mathrm{q}$ or FcyR. Although this model needs experimental verification, it is supported by several clinical observations and reconciles apparent discrepancies in the literature, and suggests a general mechanism in lgG-mediated autoimmune diseases.

Keywords: autoimmunity, immune regulation, immunoglobulin G glycosylation, galactosylation, Fc gamma receptor, complement, antibody effector functions

\section{INTRODUCTION}

Antibodies are crucial sentinels of the immune system, generated by B cells that sense incoming foreign antigens by their membrane-bound immunoglobulins or B cell receptor (BCR). With each $\mathrm{B}$ cell carrying a unique $\mathrm{BCR}$, collectively they are able to respond to virtually any invading substance, let alone a complex pathogen (1). Once recognizing their cognate antigen, each B cell becomes activated and can class switch from the initial IgM and IgD type of BCR, to immunoglobulin $\mathrm{G}$ (IgG), IgA, or IgE (2). After maturation to plasmablasts and plasma cells, the B cells start to secrete the acquired BCR in the form of soluble immunoglobulin where it can mount humoral immune responses from complement activation (IgM and $\operatorname{IgG}$ ) or cellular responses through myeloid and NK cells via Fc-receptors (all immunoglobulin types). In plasma, IgG is the most abundant immunoglobulin type found and consists of four subclasses, IgG1, IgG2, IgG3, and IgG4 in order of decreasing abundance. Since the first structures of IgG were solved, it became apparent that these structures are glycoproteins, with a conserved $\mathrm{N}$-linked $\mathrm{Fc}$-glycan attached to the asparagine found at position 297, situated in the constant region of the heavy chain domains (3) (Figure 1). However, it 

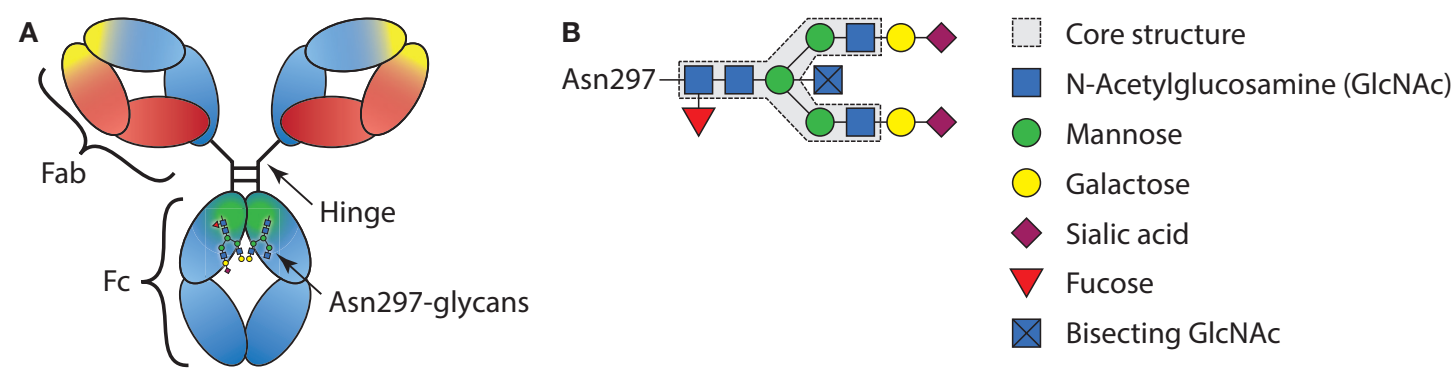

FIGURE 1 | Schematic representation of immunoglobulin G (IgG) structure and glycan composition. (A) Schematic representation of antibody with heavy chains and light chains, respectively, in blue and red, with general $Y$ shaped structure. The Fab, Fc, and hinge domains are indicated. Within the Fab domains, the antigen-binding domain is indicated in yellow and within the Fc, the region where the FcyRs and C1q bind is indicated in green. (B) Schematic representation of IgG-Fc-N297-glycan with the different sugar groups and their respective positions.

remained enigmatic if, and then how, this rather flexible structure affects the function of IgG. In recent years, these aspects have become ever more clear, although fundamental discrepancies between clinical and experimental observations seem to prevail. These observations and possible resolutions will be discussed further below.

\section{MECHANISM OF GLYCOSYLATION}

Most membrane surface proteins and secreted proteins found in plasma are glycosylated. Glycan synthesis starts at the endoplasmic reticulum (ER) when a lipid-linked precursor oligosaccharide is synthesized (Figure 2) (4). In the ER lumen, this precursor is transferred to the Asn site of the protein at accessible residues containing the Asn-X-Ser/Thr motif, where $\mathrm{X}$ is any amino acid except proline. Further processing of the glycan then takes place in the ER and Golgi apparatus, which includes trimming and remodeling of the glycan. The cell type-specific spatial and temporal organization of glycosidases and glycosyltransferase expression in ER and Golgi apparatus regulate the final composition of the glycans (4-6). For IgG, assembly of heavy and light chains takes place early in the ER (6). After initial trimming of glucose and mannose groups by the glucosidases and ER mannosidase I in the ER, the whole complex is transported to the cis-Golgi (6). The diversity of the glycans derives from several factors; involvement of many different enzymes and substrates in different compartments, variable modification of glycan core structure to bi-, tri-, and tetra-antennary, competition between enzymes for substrates and acceptors, accessibility of the enzymes to the glycan, incomplete processing, and other posttranslational modifications on the same protein (6). For the IgG N-glycans, we know they assemble in a bi-antennary glycan with a core structure of mannose and $\mathrm{N}$-acetylglucosamine groups and variable extension of galactose, sialic acid, fucose, and bisecting $N$-acetylglucosamine (bisection) (Figure 1B).

Extracellularly, glycosyltransferases and glycosidases are present in circulation, mainly editing the terminal sialic acid groups on glycans (7). This has been proven to be a functional mechanism in the sialylation of IgG, found in a study where mice with ST6GalT1-deficient B-cells did contain sialylated IgG.
This occurs through liver-derived ST6galT1 and platelet-derived CMP-sialic acid as sugar donor, which are present in the circulation (7). Although sialylation of IgG seems to be affected also in plasma, we have observed several immune responses against both red blood cell (RBC) and platelet antigens formed after transfusion or pregnancy, can have markedly different sialylation than total IgG in the same patient (8-11), suggesting that B cells can also have a significant influence on the IgG sialylation in humans. This is supported by mouse work, where they show in vivo that overexpression or knockout of sialyltransferase in B-cells attenuates IgG sialylation and disease activity in collagen-induced arthritis (12).

\section{IgG-Fc GLYCOSYLATION IN HUMANS AND IN AUTOIMMUNITY}

When analyzing normal IgG repertoire in normal human serum it is found that the overall total glycosylation pattern is, although heterogeneous, generally quite constant, with high fucosylation (96\%), low bisection (8\%), intermediate galactosylation (40\%), and low sialylation (4\%) (13). Age and gender are two factors that were found to be correlated with the overall IgG glycosylation patterns. The main variations consist of a decrease in average galactosylation and sialylation and slight increase in bisection associated with higher age (13). The degree of fucosylation is almost $100 \%$ shortly after birth (when maternal antibodies have dissipated), after which levels of IgG fucosylation gradually reach $\sim 96 \%$ around 20 years of age (14). Infection status, BMI, and epigenetic influences also seem to alter total IgG glycosylation (15-17).

Glycosylation patterns of total IgG have also been observed to temporarily change during certain conditions. During pregnancy, in particular, the degree of galactosylation and sialylation increases, with additional minor decrease in bisection while fucosylation remains stable $(18,19)$. Furthermore, in autoimmune diseases, changes in total IgG have been detected in, for example, rheumatoid arthritis (RA) (20, 21), inflammatory bowel disease (22), multiple sclerosis (23), myasthenic gravis (24), ankylosing spondylitis, primary Sjögren's syndrome, psoriatic arthritis (25), and systemic lupus erythematosus (SLE) (26). In all these diseases, a lower degree of total IgG galactosylation is 


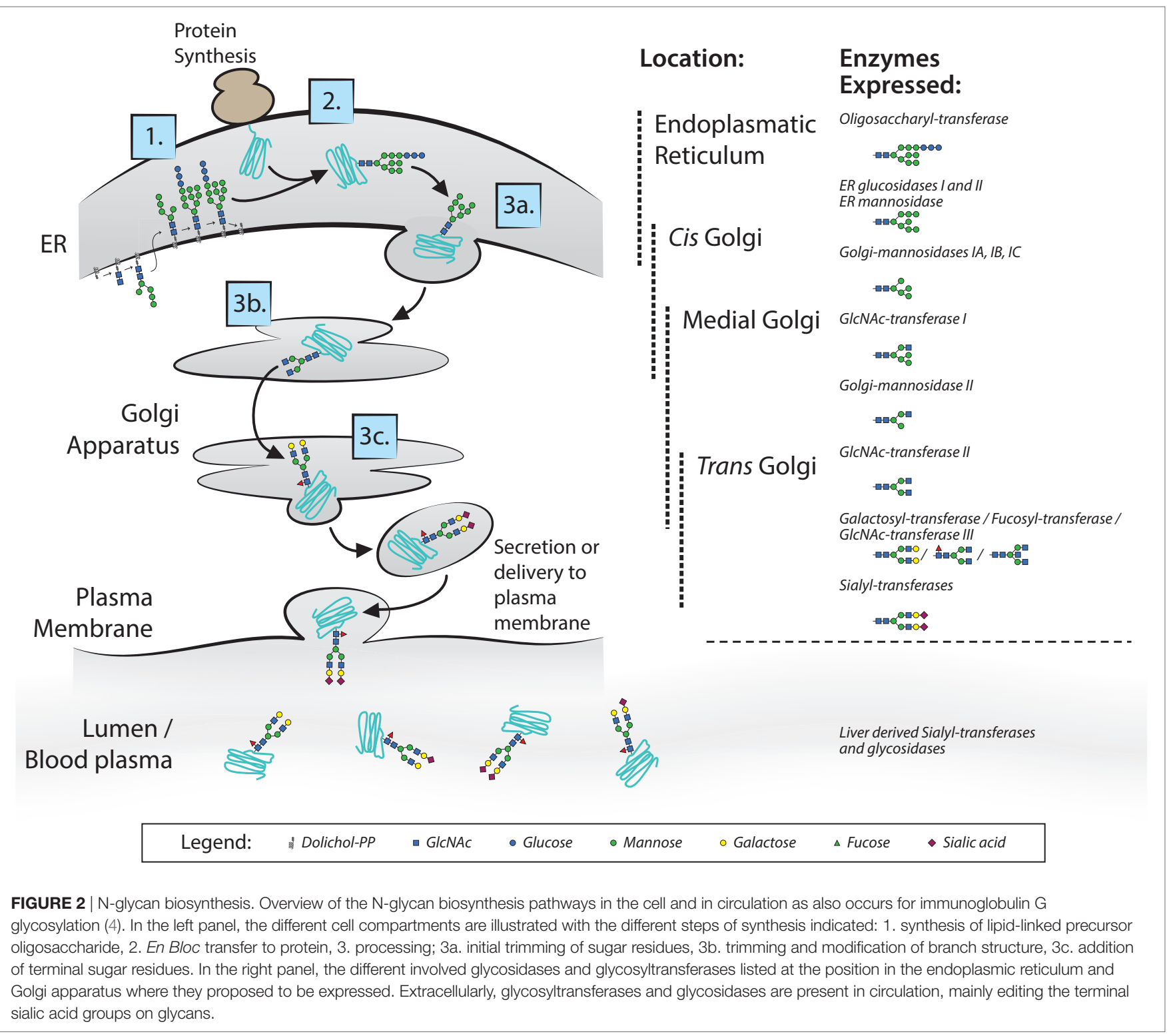

associated with disease progression and flare (20-28). However, the relevance of galactosylation of total IgG, which by definition are not causing the disease, on the disease severity is unknown. In inflammatory autoimmune disorders, such as RA and SLE, IgG autoantibodies presumably play a role in initiating or perpetuating the inflammatory condition $(29,30)$. In particular in RA, several types of autoantibodies have been identified that target a range of subtle chemical modifications of autologous proteins, including anti-citrullinated protein antibodies (ACPA) and anti-carbamylated protein antibodies-which may be referred to collectively as anti-modified protein response (31). The exact role of the autoantibodies in these diseases has not been fully elucidated as yet, although certain passive transfer mouse models suggest a pathogenic role for ACPAs (32). To our knowledge, the IgG Fc glycosylation patterns have only been determined for disease-associated autoantibodies of a few antigen-specific IgG, including ACPAs and anti-RBC autoantibodies (11, 33-37).
In all these diseases, fucosylation is not lowered, even increased for ACPA in RA $(11,33,34)$. Several studies suggest similarly low, but variable, levels of galactosylation in the antigen-specific $\operatorname{IgG}$ as found in the total $\operatorname{IgG}(11,34,35,38)$. However, in two studies, differential changes in glycosylation patterns have been observed between total IgG and specific IgG1 $(11,34)$, observed in PR3-ACPA and anti-RBC autoantibodies. In both these studies, the galactosylation was variable between the patients, with total IgG galactosylation often diverging from antigen-specific IgG galactosylation. The PR3-ANCA IgG1 antibodies also showed a particularly stable and relatively high galactosylation during relapse, while the total IgG galactosylation was lowered (34). Importantly, this may be a relevant phenomenon that may affect the disease outcome, most likely due to elevated Fc $\gamma$ RIIIa and/or Fc $\gamma$ RIIIb occupancy which is likely to affect effector functions, as will be discussed in detail in the following sections of this review. 


\section{THE IMPORTANCE OF IgG-Fc GLYCOSYLATION FOR Fc $\gamma$ R-MEDIATED EFFECTOR FUNCTIONS}

Immunoglobulin $\mathrm{G}$ binds with the $\mathrm{Fc}$ region to $\mathrm{Fc} \gamma \mathrm{Rs}$. These immune receptors are expressed on myeloid and NK cells of the immune system. Humans express five different $\mathrm{Fc} \gamma \mathrm{R}$, which can occur in several allotypic variants (39) (Figure 3). Of these five variants, FcyRIa, Fc $\gamma$ RIIa, and Fc $\gamma$ RIIIa contain an immunoreceptor tyrosine activation motif (ITAM), Fc $\gamma$ RIIb an immunoreceptor tyrosine inhibitory motif (ITIM), and Fc $\gamma$ RIIIb which is GPI-linked, contains no intracellular signaling domain (40). Binding of IgG to these receptors followed by clustering of the intracellular domains induces an ITAM-mediated signal transduction which can be counteracted by inclusion of the ITIM-containing FcyRIIb, if present (41).

Structurally, the glycan opens up the Fc-portion of IgG and keeps the two $\mathrm{CH} 2$ domains at a distance from each other, allowing for interactions with not only Fc $\gamma \mathrm{R}$ but also $\mathrm{C} 1 \mathrm{q}$ that both require similar residues in the IgG for binding (42-44). In addition to the fact that the glycan has been found to show direct, but minor, interactions with the protein backbone of Fc $\gamma R$ (43), the IgG Fc-glycan also interacts with a glycan found only in human Fc $\gamma$ RIIIa and FcyRIIIb $(45,46)$ thereby affecting binding affinity of IgG to those receptors. If, and then how, the exact glycan composition-thus not only the mere presence of a glycanaffects binding to the other $\mathrm{Fc} \gamma \mathrm{R}$ or $\mathrm{Clq}$ has remained unknown until recently, as discussed further below. The final secreted IgG eventually protects us by opsonizing incoming pathogens. These are then recognized by $F c \gamma R$, the first component of the complement system $(\mathrm{C} 1 \mathrm{q})$, or both. This can trigger multiple effector functions, such as complement deposition and lysis (47), but also Fc $\gamma$ R- and or complement-mediated phagocytosis by myeloid cells (monocytes, macrophages, or neutrophils), trogocytosis (where myeloid cells rupture the membrane of target cells), or FcyR-mediated antibody-dependent cellular cytotoxicity (ADCC) through NK or myeloid cells. These effector functions are currently utilized and have been improved upon by protein and glycan-engineering for many current and future therapeutic antibody approaches. However, these effector functions are also triggered in various allo- and autoimmune diseases (48).
In humans, we know FcyRIIIa is an important activating $\mathrm{F} c \gamma \mathrm{R}$, and of all FcyRs, its affinity for IgG is most influenced by changes in IgG Fc glycosylation. It has been known for over a decade that afucosylation increases affinity of IgG1 to Fc $\gamma$ RIIIa and FcyRIIIb $(49,50)$, and later confirmed for other IgG subclasses $(51,52)$. Earlier studies have hinted at the possibility that galactosylation may also affect binding to FcyRIIIa in a positive way (53-56), and sialylation in a negative fashion (56-59), but the effect of the other glycans had not been extensively studied. We have recently confirmed that for IgG1 additional galactosylation increases the affinity for FcyRIIIa and Fc $\gamma$ RIIIb, but only for afucosylated IgG1 (60), which is found in $6 \%$ of IgG1 at the glycopeptide level $(13,61,62)$. An overview of the effect of glycovariation on the affinity for Fc $\gamma$ Rs is displayed in Figure 4. The degree of galactosylation of IgG ranges roughly from 20 to $60 \%$ on total IgG and similarly for afucosylated IgG $(13,61,62)$. The apparent affinity increases by approximately twofold between afucosylated IgG1 with either 20 vs $70 \%$ galactosylation, which corresponds to $\sim 20 \times$ or $40 \times$ increased affinity compared to fucosylated IgG1, respectively (60).

For bisection and sialylation, we found only small effects on binding to FcyRIII. Additional sialylation of the galactosylated, afucosylated IgG1 caused a slight or no decrease in affinity (56-60). Variation in bisection did not appear to have any effect in the experiments conducted up until now, except for potentially strengthening the negative effect of sialylation on FcyRIIIa and FcyRIIIb-binding (60).

In recent years, it has become apparent that during viral infections of HIV and dengue fever, antigen-specific IgG may contain decreased levels of Fc fucosylation $(63,64)$. For HIV, this was observed especially for those patients who had a longer disease free survival, the so-called elite controllers, and this correlated with the degree of antibody-mediated cellular viral inhibition (ADCVI) of the patient's serum. In dengue, a higher degree of afucosylation was more often found in patients with antibody-dependent enhancement of disease (64). For these infections, and possibly more viral infections, the enhanced affinity for Fc $\gamma$ RIIIa of the afucosylated antigen-specific IgG indeed enhances ADCC and ADCVI of the virus and virus infected cells (65). For HIV, this rationalizes the better clinical outcome for the patients who have more antigen-specific

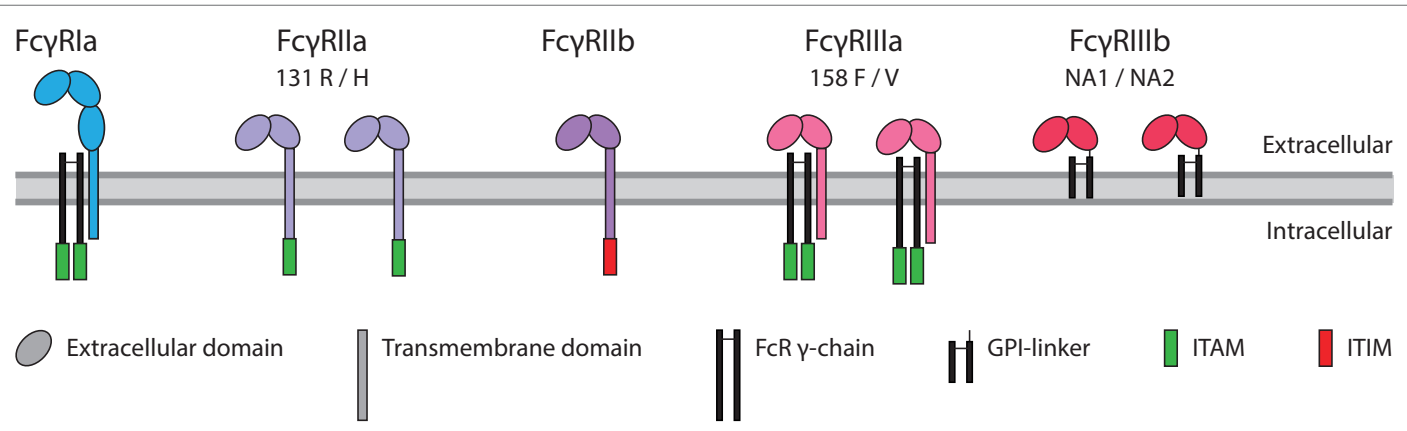

FIGURE 3 | Human FcyR family. The family of human FcyR in with allotypes indicated. Green box: immunoreceptor tyrosine activation motif (ITAM), red box: immunoreceptor tyrosine inhibitory motif (ITIM). 


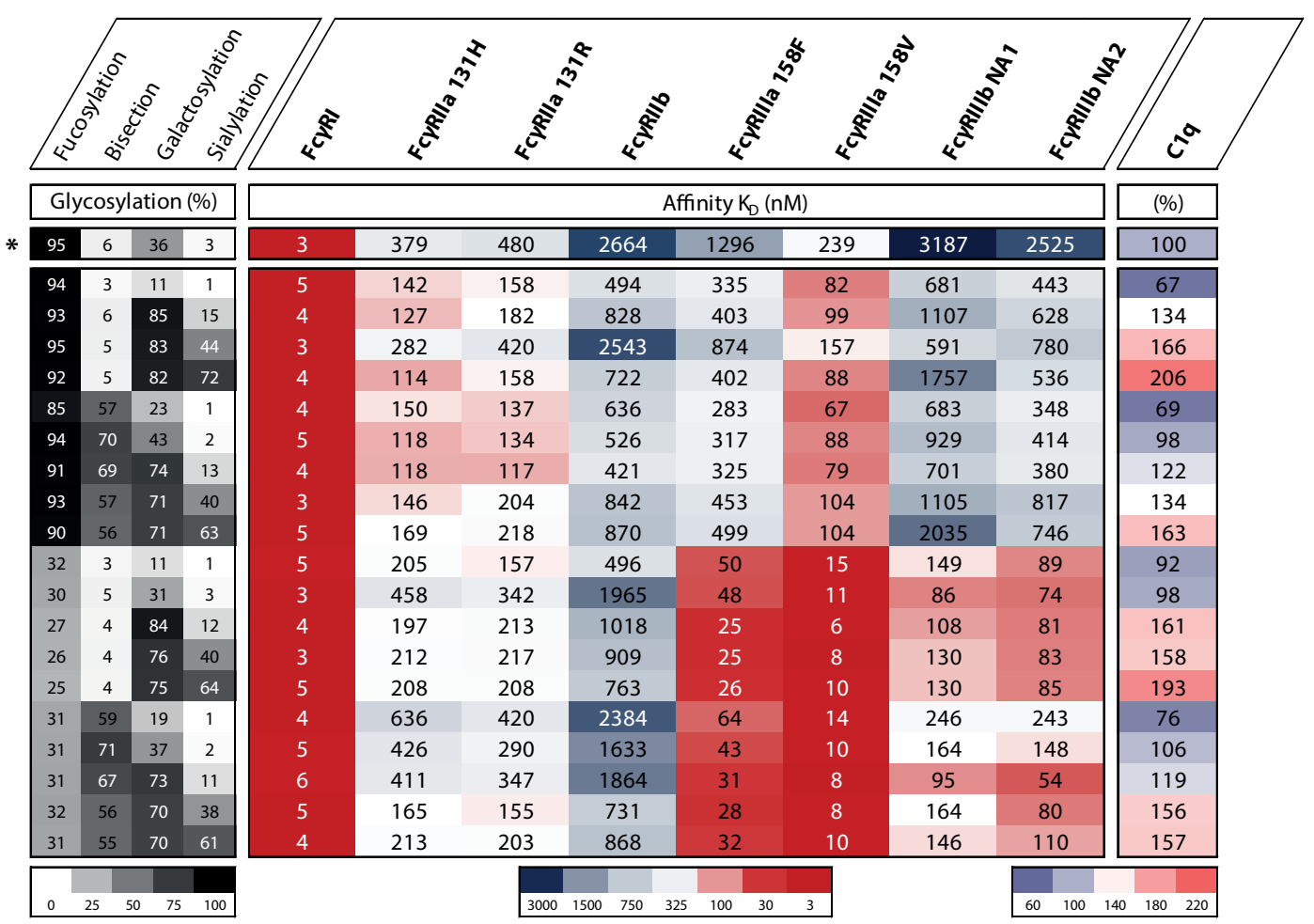

FIGURE 4 | The effect of IgG1 glycovariation and receptor affinity. Heat map displaying various glycoengineered lgG1 and their monomeric affinity in $K_{\mathrm{D}}$ (nanomolar) for the Fc $\gamma$ Rs as determined by SPR and relative affinity for C1q as determined by ELISA, data adopted from Dekkers et al. (60). Heat map legends are displayed below. The degree of glycosylation of indicated glycan end groups is colored from white (low) to black (high), the affinity to FcyRs is colored from dark blue (high $K_{\mathrm{D}}$, low affinity) via white to dark red (low $K_{\mathrm{D}}$, high affinity), the relative affinity for C1q is colored from light blue (low affinity) via white to pink (high affinity). *Indicates the normally produced, unmodified IgG1 glycoform which is not glycoengineered.

antibodies with low fucose, but for dengue, the stronger side effects have negative side effects.

Interestingly, the changes in antibody fucosylation and galactosylation of antigen-specific IgGs are also found in alloimmune settings. Examples of this are after blood transfusion, fetal neonatal immune thrombocytopenia (FNAIT) and hemolytic disease of the fetus or newborn (HDFN) $(8-10,66,67)$. Both these latter diseases are in a pregnancy setting where the fetus is positive while the mother herself is negative for a paternal antigen on platelets or RBCs, respectively, for FNAIT or HDFN, and thus makes antibodies against the blood cells of the child upon exposure. This can lead to complications and is dangerous for the health of the child and hence it is important to diagnose correctly and timely and also treat accordingly (68).

We have recently shown that glycosylation status of these antibodies matters for pathogenicity $(8,66,69)$. The lower degree of fucosylation, in particular, and also increased galactosylation of these antibodies correlate with enhanced disease severity (8-10, $66,69)$. The effector mechanism of these antibodies is thought to take place via FcyR-bearing cells in the liver and spleen of the fetus, which target the RBC or platelets (70). Previous work has already suggested that Fc $\gamma$ RIIIa is the main receptor involved in both RBC and platelet clearance because patients are more likely to carry the high-affinity FcyRIIIa allele (70, 71), now further supported by the observation that $\operatorname{IgG}$ with glycosylation patterns that target them to Fc $\gamma$ RIIIa with higher affinity also seem to correlate with enhanced disease severity in these diseases $(8-10,66)$.

As mentioned above, altered glycosylation has been detected and described for many autoimmune diseases $(20,26,28)$. This can be either in the total IgG of a patient (i.e., all IgG specificities and not directly related to the disease entity itself) (20-26) or in the IgG specific for the disease (11,33-37). Most often, a decrease in total IgG Fc-galactosylation has been found and associated with disease progression or severity $(5,20,22,26)$. By contrast, total IgG Fc galactosylation increases during pregnancy, which is clearly associated with disease remission in RA (18, 72-74). It has been shown that Fc $\gamma$ Rs are important for RA and other autoimmune diseases but axillary involvement of complement is very likely $(75,76)$. These associations have almost exclusively brought about the hypothesis that agalactosylated IgGs are proinflammatory, while highly galactosylated and sialylated IgGs are anti-inflammatory. This anti-inflammatory nature of IgG has been shown in mice not only to stem from binding of hypersialylated IgG to SIGN-R1 (in humans DC-SIGN) $(77,78)$ but also to the structural homolog and previously identified low affinity IgE-receptor CD23 (77-79). Structural changes in sialylated IgG do not seem to support this model (80-82), and work with sialicacid enriched IVIg by other groups does not support this notion (83-87). Using detailed glycoengineered IgG (60), we also find 
no binding of any glycoform to the human receptors (Temming et al. manuscript in preparation). For galactosylation, the exact role of IgG galactosylation and its influence on disease activity also needs to be further elucidated. Importantly, recent affinity data seem at odds with the widespread notion that agalactosylated IgG are pro-inflammatory, given the weaker binding of agalactosylated and afucosylated IgG to Fc $\gamma$ RIIIa in comparison to galactosylated, afucosylated IgG as described above. In addition, highly galactosylated IgG has also been associated with enhanced anti-inflammatory properties when present in immune complexes, as it apparently promotes the association of Fc $\gamma$ RIIb with Dectin-1 (88).

However, an often overlooked aspect of Fc $\gamma \mathrm{R}$ binding and subsequent activation through IgG-containing immune complexes or IgG-opsonized cells, is the fact that this occurs in the presence of high concentrations of monomeric (total) IgG in circulation. At these high concentrations (around $10 \mathrm{mg} / \mathrm{mL}$ or $60-70 \mu \mathrm{M}$, or $7 \mathrm{mg} / \mathrm{mL}$ or $40-50 \mu \mathrm{M}$ of IgG1), exceeding the $K_{\mathrm{D}}$ for binding of the most common glycoforms of IgG1 to, e.g., Fc $\gamma$ RIIa or FcyRIIIa by at least two orders of magnitude (39), most Fc receptors will be bound to monomeric IgG (i.e., a degree of saturation of ca. $98 \%$ or more). This is even higher for the high-affinity FcyRIa, which is saturated to an even higher degree, and with less displacement. Upon encounter of, e.g., an Fc $\gamma$ R-bearing cell with an opsonized cell providing higher-avidity interactions, the monomeric IgG occupying the Fc $\gamma$ R may quickly dissociate and binding of the opsonized cell will take place. How efficient this occurs will depend on the nature of the monomeric IgG (subclass and affinity); which will be strongly influenced by the relative levels of the different Fc glycovariants, but only for FcyRIIIa and FcyRIIIb.

The most important glycosylation changes affecting this are again fucosylation and galactosylation. As explained above, we and others have observed that afucosylated, highly galactosylated IgG has a higher affinity for Fc $\gamma$ RIIIa and Fc $\gamma$ RIIIb. These changes are reflected not only in the activity of NK cell to mediate ADCC via FcyRIIIa $(53,55,60,89)$ but also on how irrelevant antibodies, which may bind as monomeric entity to these $\mathrm{Fc} \gamma \mathrm{R}$, can inhibit the ADCC of specific antibodies (52). This may be relevant, e.g., in the context of RA, where during disease remission, the bulk of antibodies have a normal galactose percentage while during a flare the bulk of antibodies is lowered in galactose, including the afucosylated fraction. Of note, given the ca. 20-fold stronger binding of afucosylated IgG for Fc $\gamma \operatorname{RIII}(49,60,90)$, approximately $50 \%$ of IgGs bound to FcyRIII are expected to be afucosylated (given that the concentration of the latter is ca. 20-fold lower). Therefore, comparing a theoretical transition from a flare to remission, an elevated portion of receptor-bound monomeric IgG can be expected to consist of afucosylated, galactosylated IgG with a 2- to 3-fold higher affinity compared to afucosylated, agalactosylated IgG during remission. Under these conditions, immune complexes, in case of autoantibodies almost exclusively fucosylated judging from the current knowledge on ACPA and anti-RBC autoantibodies $(11,34,38)$, are expected to have less capacity to displace these higher-affinity IgG from the Fc $\gamma$ R. How strong this effect is, will particularly depend on the relative shifts in galactosylation profiles of the total IgG, although galactosylation changes in the autoantibodies themselves may also affect this balance (54-56). Theoretically, immune-complexes therefore have less tendency to cause crosslinking and immune activation if the bulk of IgG show relative elevated IgG-Fc galactosylation, and hence have diminished capacity to cause disease (Figure 5). Overall, the altered glycosylation profiles of autoantibodies may result in altered FcyR-binding and activation, but this may be attenuated by altered glycosylation profiles of non-specific total IgG. We should, of course, realize that all these autoimmune diseases are characterized by multifactorial components, ultimately resulting in disease onset and progression. For RA, this includes the acquirement of multiple disease factors, such as infiltration of immune cells into the joint, ACPA, anti-hinge antibodies, rheumatoid factor (IgM based), increased TNF levels, and complement discussed below $(75,91)$.

\section{THE IMPORTANCE OF IgG-Fc GLYCOSYLATION FOR COMPLEMENT- MEDIATED FUNCTIONS}

Fc glycosylation-the presence of the Fc glycan-is important for classical complement activation, has been known already for a long time $(42,92)$. In RA, the complement system has been suggested to play an important part of the pathological features, and so have changes in IgG Fc glycosylation are in the galactose end groups $(18,20,93)$. The same seems true for many other autoimmune disease where lowered IgG-Fc galactosylation of total IgG correlates with disease severity $(5,11,20,22,26)$. One study proposed that activation of complement by these agalactosylated IgG species involves specific recognition by the mannose-binding lectin and activation through the lectin pathway of complement activation (94). However, to our knowledge, these results have never been verified. In contrary, we have recently found that IgG agalactosylation-irrespective of all other glycan end groups-does not induce activation of complement via the lectin pathway, confirming various other studies on this subject $(60,95,96)$. This seems to leave the classical pathway as the main route for enhanced disease activity possibly affected by IgG-Fc glycan variations, by binding of antibody (complexes) to C1q, although deviations from this are likely to exist depending on the disease etiology.

Having established that low galactosylation of total IgG seems to correlate with enhanced disease activity in several autoimmune diseases where complement seem to play an important role $(5,11,20,22,26)$, has led to the suggestion that agaloctosylated $\operatorname{IgG}$ is pro-inflammatory with enhanced complement activity. In contrary, several publications seem now to suggest the opposite to be true. While a few studies found that fucosylation does not affect complement-mediated activity $(49,51,60)$, two recent studies suggest that galactosylation of human IgG positively affects $\mathrm{Clq}$ binding and downstream activation $(60,97,98)$. In our recent study where we screened 20 different and highly defined IgG glycovariants for $\mathrm{Clq}$ binding and activation, we found that galactosylation primarily enhanced $\mathrm{C} 1 \mathrm{q}$ binding and increased $\mathrm{CDC}$ and that additional sialylation increases this effect on the classical complement activation 

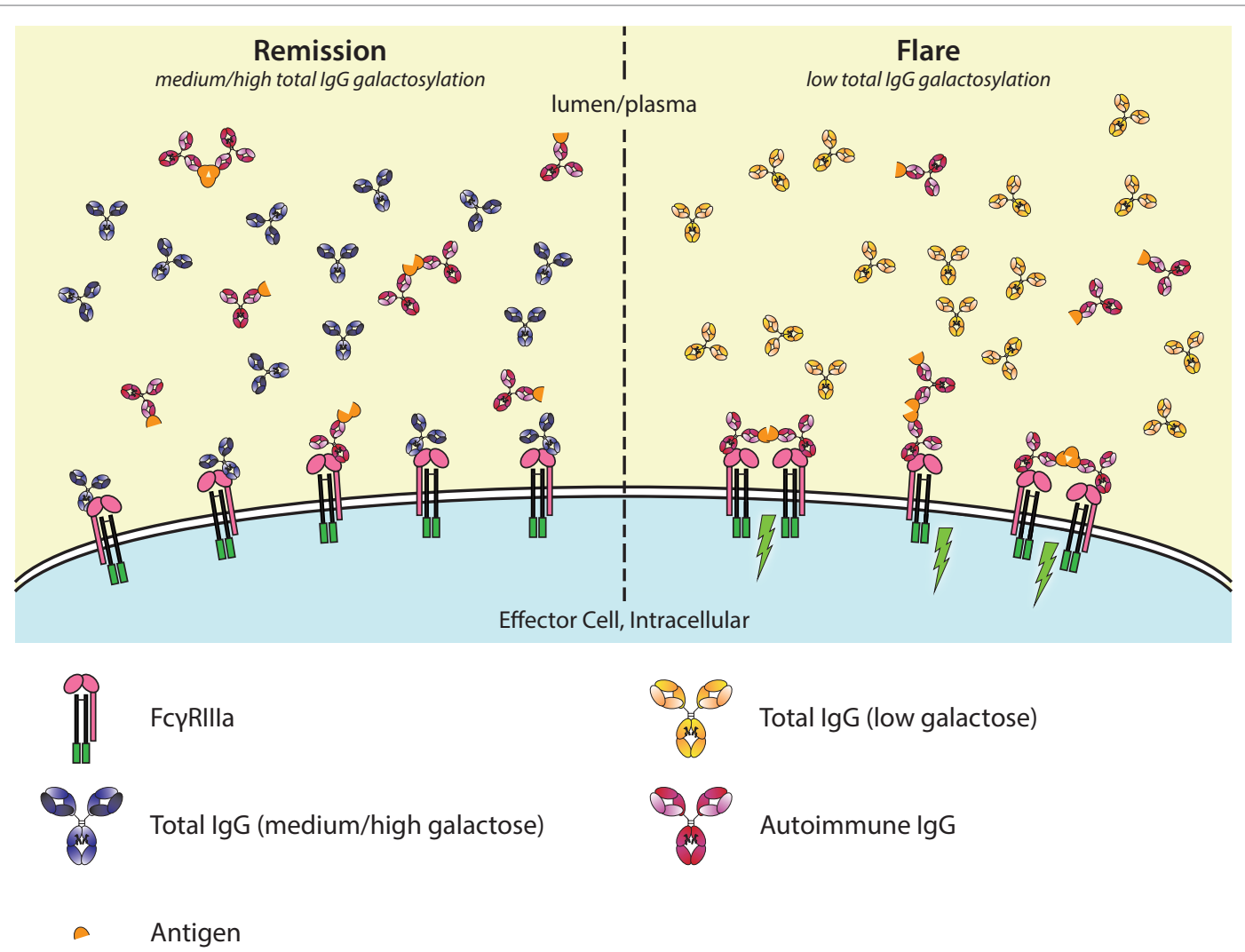

FIGURE 5 | Galactosylation of total immunoglobulin G (lgG) affects IgG-occupation of FcyRIlla, affecting activation thresholds and flares in autoimmunity. In autoimmune diseases, such as rheumatoid arthritis, disease severity is negatively correlated with the degree of galactosylation. Galactosylation of IgG is important for binding to FcyRllla, where-in combination with afucosylation-a higher degree of IgG-Fc galactosylation increases the affinity. Only 6\% of normal serum IgGs is afucosylated. During remission (left), the total lgG galactosylation is relatively high, which prevents autoantibodies to engage the Fc $\gamma$ Rs. During a flare of disease (right), the total IgG galactosylation is low, which reduces the overall binding affinity of total IgG to Fc $\gamma R$ III, and therefore lowers the threshold for Fc $\gamma R$-activation by allowing more easy access by pathogenic autoantibodies, causing immune activation (green lightning bolt).

pathway. Bisection showed no affect in any combination with fucose, galactose, or sialylation (60) (Figure 4). Similarly, Quast et al. (97) showed that increased galactosylation enhances $\mathrm{Clq}$ binding and CDC in antibody models, where CDC is the main effector function. However, in their model, the addition of sialic acid hampered this enhanced effect (97). The difference in effector function might depend on the nature of the antigen, effector cells, and/or target cells. This is plausible as hexamerization of IgG on the surface of the target is likely needed for proper binding and activation of $\mathrm{Clq}$, and the propensity of different antibodies/antigens to do this may vary as they take on different molecular configurations $(99,100)$. Much more research on this mechanism is, however, required as we do not know how the specificity of the IgG influences this effect or whether these changes are also relevant in a setting where IgG is already enhanced for CDC by protein engineering $(101,102)$.

It may seem counterintuitive that agalactosylated IgG has been associated with higher pathogenicity while new studies with glycoengineered IgG shows it to have lower potential to activate $\mathrm{Clq}$ compared to galactosylated IgG. A possible explanation may be similar to that what we propose for Fc $\gamma$ Rs (Figure 6). During remission, total IgG galactosylation is relatively high, while during a flare of the autoimmune disease the total IgG galactosylation is relatively low. In the latter case, the threshold for activation of $\mathrm{C1q}$ might be lowered due to lower steady-state occupancy by the low-galactosylated IgG. If so, then this could allow for relatively increase in activation of complement by pathogenic IgG complexed by its cognate autoantigen.

Although the binding affinity of monomeric to IgG has been estimated to be very low, i.e., in the $20-100 \mu \mathrm{M}$ range (103-106), we again have to take into account the exceptionally high concentration of IgG in serum, making this model plausible. Considering IgG1, present at concentrations around $40-50 \mu \mathrm{M}$, this translates to ca. 30-70\% saturation of C1q. However, care should be taken as measurements of the affinity of monomeric IgG binding to $\mathrm{Clq}$ might have been influenced by the presence of trace amounts of aggregates, resulting in an overestimation of the deduced affinities.

Furthermore, we do not know how well these biochemical principles translate into the in vivo setting. This could be experimentally determined, but needs high concentrations of both $\mathrm{IgG}$ and $\mathrm{Clq}$ as the monomeric affinity is generally very low. However, it is important to keep in mind that we do not yet 


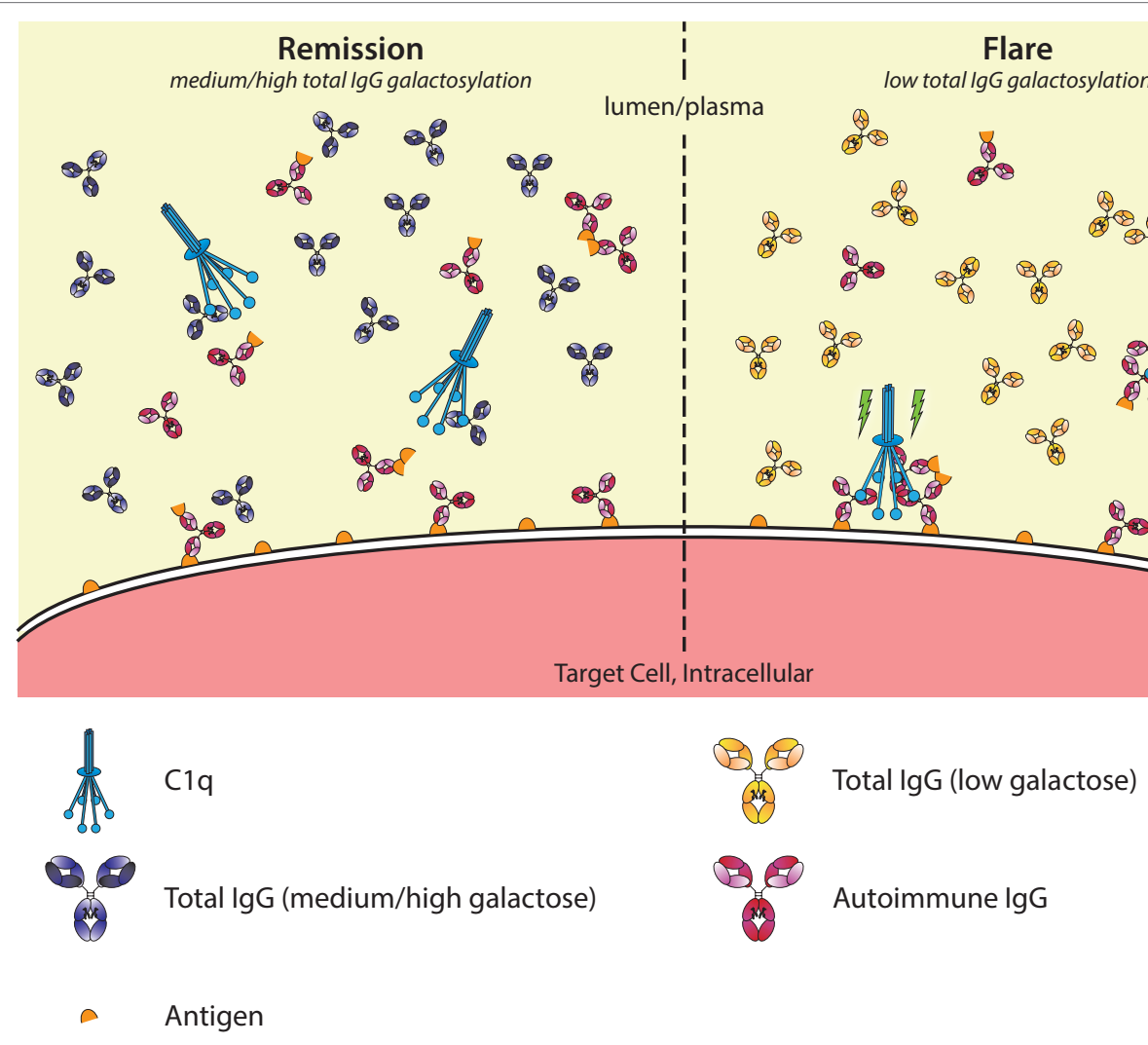

FIGURE 6 | Galactosylation of total immunoglobulin G (IgG) affects C1q occupation and activation in autoimmune remission and flare. In autoimmune diseases, such as rheumatoid arthritis, disease severity is negatively correlated with the degree of galactosylation found in total lgG. Galactosylation of IgG is important for binding to C1q, where a higher degree of IgG Fc galactosylation-and sialylation-increases the affinity. Additionally, C19 requires multimerization/hexamers of lgG for proper activation. During remission (left), C1q-autoantibody engagement might be prevented by preferential interaction with aspecific highly galactosylated IgG, which is abundantly present. During a flare (right), the total lgG galactosylation is low, which reduces the overall threshold of $\mathrm{C} 1 \mathrm{q}$ binding, allowing for relatively better binding of pathogenic $\lg \mathrm{G} / \mathrm{immune}$ complexes, allowing activation of the classical complement pathway (green lightning bolt).

know whether the observed changes in IgG galactosylation in, for example, RA are truly causative of disease flares or a response to the flares. Efforts to investigate the causative association should be undertaken.

\section{CONCLUSION}

All in all, it was shown that glycan alterations found in IgG seem to be driven by the type of response and have functional consequences. The knowledge that afucosylation imposes better effector functions has already been put to use to enhance the function of therapeutic antibodies used in cancer treatment (107, 108). Additional glycoengineering of the galactose end groups could thus even further improve the functionality of these antibodies. These changes do occur naturally in humans as they are formed in certain immune reactions resulting in stronger humoral immune responses $(9,63,64,66,69)$. For autoimmune mediated diseases, where changes in galactosylation in both the bulk and the pathogenic antibodies are frequently found, glycosylation changes effects both of binding to $\mathrm{Fc} \gamma \mathrm{R}$ and $\mathrm{C} 1 \mathrm{q}$, which in turn affects their downstream activation. Based on the current evidence, the glycan changes in the bulk of endogenous IgG have the opposite effect on what is observed for antigen-specific IgG. Skewing toward lowered levels of galactose of the bulk IgG lowers its potential to efficiently block both $\mathrm{Fc} \gamma \mathrm{R}$, but also potentially $\mathrm{C} 1 \mathrm{q}$, giving more room for activation by existing pathogenic IgG-complexes. Eventually, it might be possible to monitor the glycosylation status, especially degree of galactosylation, of the total or disease-specific antibodies in autoimmune diseases. This could help to predict or detect an upcoming flare in autoimmune diseases, enabling intervention early after, or even before symptoms to set in.

\section{AUTHOR CONTRIBUTIONS}

GD composed and made the figures. GD, TR, and GV wrote and edited the manuscript.

\section{FUNDING}

This study was supported by Sanquin Product and Process Development Plasma Products, 12-001, Gestur Vidarsson. 


\section{REFERENCES}

1. Hoehn KB, Fowler A, Lunter G, Pybus OG. The diversity and molecular evolution of B-cell receptors during infection. Mol Biol Evol (2016) 33:1147-57. doi:10.1093/molbev/msw015

2. Vidarsson G, Dekkers G, Rispens T. IgG subclasses and allotypes: from structure to effector functions. Front Immunol (2014) 5:520. doi:10.3389/ fimmu.2014.00520

3. Huber R, Deisenhofer J, Colman PM, Matsushima M, Palm W. Crystallographic structure studies of an IgG molecule and an Fc fragment. Nature (1976) 264:415-20. doi:10.1038/264415a0

4. Taylor ME, Drickamer K. Introduction to Glycobiology. 3rd ed. New York, NY: Oxford University Press Inc. (2011).

5. Maverakis E, Kim K, Shimoda M, Gershwin ME, Patel F, Wilken R, et al. Glycans in the immune system and The Altered Glycan Theory of Autoimmunity: a critical review. J Autoimmun (2015) 57:1-13. doi:10.1016/j. jaut.2014.12.002

6. Hristodorov D, Fischer R, Linden L. With or without sugar? (A)glycosylation of therapeutic antibodies. Mol Biotechnol (2013) 54:1056-68. doi:10.1007/ s12033-012-9612-x

7. Jones MB, Oswald DM, Joshi S, Whiteheart SW, Orlando R, Cobb BA. B-cell-independent sialylation of IgG. Proc Natl Acad Sci U S A (2016) 113:7207-12. doi:10.1073/pnas.1523968113

8. Kapur R, Kustiawan I, Vestrheim A, Koeleman CAM, Visser R, Einarsdottir HK, et al. A prominent lack of IgG1-Fc fucosylation of platelet alloantibodies in pregnancy. Blood (2014) 123:471-80. doi:10.1182/blood-2013-09-527978

9. Sonneveld ME, Natunen S, Sainio S, Koeleman CAM, Holst S, Dekkers G, et al. Glycosylation pattern of anti-platelet IgG is stable during pregnancy and predicts clinical outcome in alloimmune thrombocytopenia. Br J Haematol (2016) 174:310-20. doi:10.1111/bjh.14053

10. Sonneveld ME, Koelewijn J, de Haas M, Admiraal J, Plomp R, Koeleman CAM, et al. Antigen specificity determines anti-red blood cell IgG-Fc alloantibody glycosylation and thereby severity of haemolytic disease of the fetus and newborn. Br J Haematol (2017) 176:651-60. doi:10.1111/bjh.14438

11. Sonneveld ME, de Haas M, Koeleman C, de Haan N, Zeerleder SS, Ligthart PC, et al. Patients with IgG1-anti-red blood cell autoantibodies show aberrant Fc-glycosylation. Sci Rep (2017) 7:8187. doi:10.1038/s41598017-08654-y

12. Ohmi Y, Ise W, Harazono A, Takakura D, Fukuyama H, Baba Y, et al. Sialylation converts arthritogenic IgG into inhibitors of collagen-induced arthritis. Nat Commun (2016) 7:11205. doi:10.1038/ncomms11205

13. Baković MP, Selman MHJ, Hoffmann M, Rudan I, Campbell H, Deelder AM, et al. High-throughput IgG Fc N-glycosylation profiling by mass spectrometry of glycopeptides. J Proteome Res (2013) 12:821-31. doi:10.1021/ pr300887z

14. de Haan N, Reiding KR, Driessen G, van der Burg M, Wuhrer M. Changes in healthy human IgG Fc-glycosylation after birth and during early childhood. J Proteome Res (2016) 15:1853-61. doi:10.1021/acs.jproteome.6b00038

15. Menni C, Keser T, Mangino M, Bell JT, Erte I, Akmačić I, et al. Glycosylation of immunoglobulin g: role of genetic and epigenetic influences. PLoS One (2013) 8:e82558. doi:10.1371/journal.pone.0082558

16. Nikolac Perkovic M, Pucic Bakovic M, Kristic J, Novokmet M, Huffman JE, Vitart V, et al. The association between galactosylation of immunoglobulin G and body mass index. Prog Neuropsychopharmacol Biol Psychiatry (2014) 48:20-5. doi:10.1016/j.pnpbp.2013.08.014

17. Pucić M, Knezević A, Vidic J, Adamczyk B, Novokmet M, Polasek O, et al. High throughput isolation and glycosylation analysis of IgG-variability and heritability of the IgG glycome in three isolated human populations. Mol Cell Proteomics (2011) 10:M111.010090. doi:10.1074/mcp.M111.010090

18. Bondt A, Selman MHJ, Deelder AM, Hazes JMW, Willemsen SP, Wuhrer M, et al. Association between galactosylation of immunoglobulin $\mathrm{G}$ and improvement of rheumatoid arthritis during pregnancy is independent of sialylation. J Proteome Res (2013) 12:4522-31. doi:10.1021/pr400589m

19. Bondt A, Rombouts Y, Selman MHJ, Hensbergen PJ, Reiding KR, Hazes JMW, et al. Immunoglobulin G (IgG) Fab glycosylation analysis using a new mass spectrometric high-throughput profiling method reveals pregnancyassociated changes. Mol Cell Proteomics (2014) 13:3029-39. doi:10.1074/ mcp.M114.039537
20. Parekh RB, Dwek RA, Sutton BJ, Fernandes DL, Leung A, Stanworth D, et al. Association of rheumatoid arthritis and primary osteoarthritis with changes in the glycosylation pattern of total serum IgG. Nature (1985) 316:452-7. doi: $10.1038 / 316452 \mathrm{a} 0$

21. Ercan A, Cui J, Chatterton DEW, Deane KD, Hazen MM, Brintnell W, et al. Aberrant IgG galactosylation precedes disease onset, correlates with disease activity, and is prevalent in autoantibodies in rheumatoid arthritis. Arthritis Rheum (2010) 62:2239-48. doi:10.1002/art.27533

22. Trbojević Akmačić I, Ventham NT, Theodoratou E, Vučković F, Kennedy NA, Krištić J, et al. Inflammatory bowel disease associates with proinflammatory potential of the immunoglobulin G glycome. Inflamm Bowel Dis (2015) 21:1237-47. doi:10.1097/MIB.0000000000000372

23. Wuhrer M, Selman MHJ, McDonnell LA, Kümpfel T, Derfuss T, Khademi M, et al. Pro-inflammatory pattern of IgG1 Fc glycosylation in multiple sclerosis cerebrospinal fluid. J Neuroinflammation (2015) 12:235. doi:10.1186/s12974-015-0450-1

24. Selman MHJ, Niks EH, Titulaer MJ, Verschuuren JJGM, Wuhrer M, Deelder AM. IgG fc N-glycosylation changes in Lambert-Eaton myasthenic syndrome and myasthenia gravis. J Proteome Res (2011) 10:143-52. doi:10.1021/pr1004373

25. Watson M, Rudd PM, Bland M, Dwek RA, Axford JS. Sugar printing rheumatic diseases: a potential method for disease differentiation using immunoglobulin G oligosaccharides. Arthritis Rheum (1999) 42:1682-90. doi:10.1002/1529-0131(199908)42:8<1682:AID-ANR17>3.0.CO;2-X

26. Vučković F, Krištić J, Gudelj I, Teruel M, Keser T, Pezer M, et al. Association of systemic lupus erythematosus with decreased immunosuppressive potential of the IgG glycome. Arthritis Rheumatol (2015) 67:2978-89. doi:10.1002/ art. 39273

27. Förger F, Ostensen $M$. Is IgG galactosylation the relevant factor for pregnancy-induced remission of rheumatoid arthritis? Arthritis Res Ther (2010) 12:108. doi:10.1186/ar2919

28. Biermann MHC, Griffante G, Podolska MJ, Boeltz S, Stürmer J, Muñoz LE, et al. Sweet but dangerous - the role of immunoglobulin $\mathrm{G}$ glycosylation in autoimmunity and inflammation. Lupus (2016) 25:934-42. doi:10.1177/ 0961203316640368

29. Bax M, Huizinga TWJ, Toes REM. The pathogenic potential of autoreactive antibodies in rheumatoid arthritis. Semin Immunopathol (2014) 36:313-25. doi:10.1007/s00281-014-0429-5

30. Conigliaro P, Chimenti MS, Triggianese P, Sunzini F, Novelli L, Perricone C, et al. Autoantibodies in inflammatory arthritis. Autoimmun Rev (2016) 15:673-83. doi:10.1016/j.autrev.2016.03.003

31. Trouw LA, Rispens T, Toes REM. Beyond citrullination: other posttranslational protein modifications in rheumatoid arthritis. Nat Rev Rheumatol (2017) 13:331-9. doi:10.1038/nrrheum.2017.15

32. Kuhn KA, Kulik L, Tomooka B, Braschler KJ, Arend WP, Robinson WH, et al. Antibodies against citrullinated proteins enhance tissue injury in experimental autoimmune arthritis. J Clin Invest (2006) 116:961-73. doi:10.1172/ JCI25422

33. Rombouts Y, Ewing E, van de Stadt LA, Selman MHJ, Trouw LA, Deelder AM, et al. Anti-citrullinated protein antibodies acquire a pro-inflammatory $\mathrm{Fc}$ glycosylation phenotype prior to the onset of rheumatoid arthritis. Ann Rheum Dis (2015) 74:234-41. doi:10.1136/annrheumdis-2013-203565

34. Kemna MJ, Plomp R, van Paassen P, Koeleman CAM, Jansen BC, Damoiseaux JGMC, et al. Galactosylation and sialylation levels of IgG predict relapse in patients with PR3-ANCA associated vasculitis. EBioMedicine (2017) 17:108-18. doi:10.1016/j.ebiom.2017.01.033

35. Scherer HU, van der Woude D, Ioan-Facsinay A, el Bannoudi H, Trouw LA, Wang J, et al. Glycan profiling of anti-citrullinated protein antibodies isolated from human serum and synovial fluid. Arthritis Rheum (2010) 62:1620-9. doi:10.1002/art.27414

36. Magorivska I, Muñoz LE, Janko C, Dumych T, Rech J, Schett G, et al. Sialylation of anti-histone immunoglobulin $\mathrm{G}$ autoantibodies determines their capabilities to participate in the clearance of late apoptotic cells. Clin Exp Immunol (2016) 184:110-7. doi:10.1111/cei.12744

37. Fickentscher C, Magorivska I, Janko C, Biermann M, Bilyy R, Nalli C, et al. The pathogenicity of anti- $\beta 2 \mathrm{GP} 1-\operatorname{IgG}$ autoantibodies depends on Fc glycosylation. J Immunol Res (2015) 2015:638129. doi:10.1155/2015/ 638129 
38. Rombouts Y, Willemze A, van Beers JJBC, Shi J, Kerkman PF, van Toorn L, et al. Extensive glycosylation of ACPA-IgG variable domains modulates binding to citrullinated antigens in rheumatoid arthritis. Ann Rheum Dis (2016) 75:578-85. doi:10.1136/annrheumdis-2014-206598

39. Bruhns P, Iannascoli B, England P, Mancardi DA, Fernandez N, Jorieux S, et al. Specificity and affinity of human Fcgamma receptors and their polymorphic variants for human IgG subclasses. Blood (2009) 113:3716-25. doi:10.1182/blood-2008-09-179754

40. Powell MS, Hogarth PM. Fc receptors. Adv Exp Med Biol (2008) 640:22-34. doi:10.1007/978-0-387-09789-3_3

41. Getahun A, Cambier JC. Of ITIMs, ITAMs, and ITAMis: revisiting immunoglobulin Fc receptor signaling. Immunol Rev (2015) 268:66-73. doi:10.1111/ imr.12336

42. Duncan AR, Winter G. The binding site for C1q on IgG. Nature (1988) 332:738-40. doi:10.1038/332738a0

43. Sondermann P, Huber R, Oosthuizen V, Jacob U. The 3.2-A crystal structure of the human IgG1 Fc fragment-Fc gammaRIII complex. Nature (2000) 406:267-73. doi:10.1038/35018508

44. Ramsland PA, Farrugia W, Bradford TM, Sardjono CT, Esparon S, Trist HM, et al. Structural basis for Fc gammaRIIa recognition of human IgG and formation of inflammatory signaling complexes. J Immunol (2011) 187:3208-17. doi:10.4049/jimmunol.1101467

45. Ferrara C, Stuart F, Sondermann P, Brünker P, Umaña P. The carbohydrate at FcgammaRIIIa Asn-162. An element required for high affinity binding to non-fucosylated IgG glycoforms. J Biol Chem (2006) 281:5032-6. doi:10.1074/jbc.M510171200

46. Ferrara C, Grau S, Jäger C, Sondermann P, Brünker P, Waldhauer I, et al. Unique carbohydrate-carbohydrate interactions are required for high affinity binding between FcgammaRIII and antibodies lacking core fucose. Proc Natl Acad Sci U S A (2011) 108:12669-74. doi:10.1073/pnas.1108455108

47. Merle NS, Church SE, Fremeaux-Bacchi V, Roumenina LT. Complement system part I - molecular mechanisms of activation and regulation. Front Immunol (2015) 6:262. doi:10.3389/fimmu.2015.00262

48. Dijstelbloem HM, van de Winkel JG, Kallenberg CGM. Inflammation in autoimmunity: receptors for IgG revisited. Trends Immunol (2001) 22:510-6. doi:10.1016/S1471-4906(01)02014-2

49. Shields RL, Lai J, Keck R, O’Connell LY, Hong K, Meng YG, et al. Lack of fucose on human IgG1 N-linked oligosaccharide improves binding to human Fcgamma RIII and antibody-dependent cellular toxicity. J Biol Chem (2002) 277:26733-40. doi:10.1074/jbc.M202069200

50. Shinkawa T, Nakamura K, Yamane N, Shoji-Hosaka E, Kanda Y, Sakurada M, et al. The absence of fucose but not the presence of galactose or bisecting $\mathrm{N}$-acetylglucosamine of human IgG1 complex-type oligosaccharides shows the critical role of enhancing antibody-dependent cellular cytotoxicity. J Biol Chem (2003) 278:3466-73. doi:10.1074/jbc.M210665200

51. Niwa R, Natsume A, Uehara A, Wakitani M, Iida S, Uchida K, et al. IgG subclass-independent improvement of antibody-dependent cellular cytotoxicity by fucose removal from Asn297-linked oligosaccharides. J Immunol Methods (2005) 306:151-60. doi:10.1016/j.jim.2005.08.009

52. Bruggeman CW, Dekkers G, Bentlage AEH, Treffers LW, Nagelkerke SQ, Lissenberg-Thunnissen S, et al. Enhanced effector functions due to antibody defucosylation depend on the effector cell $\mathrm{Fc} \gamma$ receptor profile. J Immunol (2017) 199:204-11. doi:10.4049/jimmunol.1700116

53. Houde D, Peng Y, Berkowitz SA, Engen JR. Post-translational modifications differentially affect IgG1 conformation and receptor binding. Mol Cell Proteomics (2010) 9:1716-28. doi:10.1074/mcp.M900540-MCP200

54. Dashivets T, Thomann M, Rueger P, Knaupp A, Buchner J, Schlothauer T. Multi-angle effector function analysis of human monoclonal IgG glycovariants. PLoS One (2015) 10:e0143520. doi:10.1371/journal.pone.0143520

55. Thomann M, Schlothauer T, Dashivets T, Malik S, Avenal C, Bulau P, et al. In vitro glycoengineering of IgG1 and its effect on Fc receptor binding and ADCC activity. PLoS One (2015) 10:e0134949. doi:10.1371/journal. pone. 0134949

56. Subedi GP, Barb AW. The immunoglobulin G1 N-glycan composition affects binding to each low affinity Fc $\gamma$ receptor. MAbs (2016) 8:1512-24. doi:10.1080/19420862.2016.1218586

57. Kaneko Y, Nimmerjahn F, Ravetch JV. Anti-inflammatory activity of immunoglobulin G resulting from Fc sialylation. Science (2006) 313:670-3. doi:10.1126/science.1129594
58. Li T, DiLillo DJ, Bournazos S, Giddens JP, Ravetch JV, Wang L-X. Modulating IgG effector function by Fc glycan engineering. Proc Natl Acad Sci U S A (2017) 114:3485-90. doi:10.1073/pnas.1702173114

59. Scallon BJ, Tam SH, McCarthy SG, Cai AN, Raju TS. Higher levels of sialylated Fc glycans in immunoglobulin $G$ molecules can adversely impact functionality. Mol Immunol (2007) 44:1524-34. doi:10.1016/j. molimm.2006.09.005

60. Dekkers G, Treffers L, Plomp R, Bentlage AEH, de Boer M, Koeleman CAM, et al. Decoding the human immunoglobulin G-glycan repertoire reveals a spectrum of Fc-receptor- and complement-mediated-effector activities. Front Immunol (2017) 8:877. doi:10.3389/fimmu.2017.00877

61. Fokkink WJR, Falck D, Santbergen TCM, Huizinga R, Wuhrer M, Jacobs BC. Comparison of Fc N-glycosylation of pharmaceutical products of Intravenous Immunoglobulin G. PLoS One (2015) 10:e0139828. doi:10.1371/journal. pone. 0139828

62. Huhn C, Selman MHJ, Ruhaak LR, Deelder AM, Wuhrer M. IgG glycosylation analysis. Proteomics (2009) 9:882-913. doi:10.1002/pmic.200800715

63. Ackerman ME, Crispin M, Yu X, Baruah K, Boesch AW, Harvey DJ, et al. Natural variation in Fc glycosylation of HIV-specific antibodies impacts antiviral activity. J Clin Invest (2013) 123:2183-92. doi:10.1172/ JCI65708

64. Wang TT, Sewatanon J, Memoli MJ, Wrammert J, Bournazos S, Bhaumik SK, et al. IgG antibodies to dengue enhanced for FcyRIIIA binding determine disease severity. Science (2017) 355:395-8. doi:10.1126/science.aai8128

65. Moldt B, Shibata-Koyama M, Rakasz EG, Schultz N, Kanda Y, Dunlop DC, et al. A nonfucosylated variant of the anti-HIV-1 monoclonal antibody b12 has enhanced FcyRIIIa-mediated antiviral activity in vitro but does not improve protection against mucosal SHIV challenge in macaques. J Virol (2012) 86:6189-96. doi:10.1128/JVI.00491-12

66. Kapur R, Della Valle L, Sonneveld M, Hipgrave Ederveen A, Visser R, Ligthart $\mathrm{P}$, et al. Low anti-RhD IgG-Fc-fucosylation in pregnancy: a new variable predicting severity in haemolytic disease of the fetus and newborn. Br J Haematol (2014) 166:936-45. doi:10.1111/bjh.12965

67. Kapur R, Della Valle L, Verhagen OJHM, Hipgrave Ederveen A, Ligthart P, de Haas M, et al. Prophylactic anti-D preparations display variable decreases in Fc-fucosylation of anti-D. Transfusion (2015) 55:553-62. doi:10.1111/ trf. 12880

68. Urbaniak SJ, Greiss MA. RhD haemolytic disease of the fetus and the newborn. Blood Rev (2000) 14:44-61. doi:10.1054/blre.1999.0123

69. Wuhrer M, Porcelijn L, Kapur R, Koeleman CAM, Deelder A, de Haas M, et al. Regulated glycosylation patterns of IgG during alloimmune responses against human platelet antigens. J Proteome Res (2009) 8:450-6. doi:10.1021/ pr800651j

70. Stegmann TC, Veldhuisen B, Nagelkerke SQ, Winkelhorst D, Schonewille H, Verduin EP, et al. RhIg-prophylaxis is not influenced by FCGR2/3 polymorphisms involved in red blood cell clearance. Blood (2017) 129:1045-8. doi:10.1182/blood-2016-05-716365

71. Breunis WB, van Mirre E, Bruin M, Geissler J, de Boer M, Peters M, et al. Copy number variation of the activating FCGR2C gene predisposes to idiopathic thrombocytopenic purpura. Blood (2008) 111:1029-38. doi:10.1182/ blood-2007-03-079913

72. Ruhaak LR, Uh H-W, Deelder AM, Dolhain REJM, Wuhrer M. Total plasma N-glycome changes during pregnancy. J Proteome Res (2014) 13:1657-68. doi:10.1021/pr401128j

73. Rook GA, Steele J, Brealey R, Whyte A, Isenberg D, Sumar N, et al. Changes in IgG glycoform levels are associated with remission of arthritis during pregnancy. J Autoimmun (1991) 4:779-94. doi:10.1016/08968411(91)90173-A

74. van de Geijn FE, Wuhrer M, Selman MH, Willemsen SP, de Man YA, Deelder AM, et al. Immunoglobulin G galactosylation and sialylation are associated with pregnancy-induced improvement of rheumatoid arthritis and the postpartum flare: results from a large prospective cohort study. Arthritis Res Ther (2009) 11:R193. doi:10.1186/ar2892

75. el Bannoudi H, Ioan-Facsinay A, Toes REM. Bridging autoantibodies and arthritis: the role of Fc receptors. Curr Top Microbiol Immunol (2014) 382:303-19. doi:10.1007/978-3-319-07911-0_14

76. Thabet MM, Huizinga TWJ, Marques RB, Stoeken-Rijsbergen G, Bakker AM, Kurreeman FA, et al. Contribution of Fcgamma receptor IIIA gene 158V/F polymorphism and copy number variation to the risk of ACPA-positive 
rheumatoid arthritis. Ann Rheum Dis (2009) 68:1775-80. doi:10.1136/ ard.2008.099309

77. Anthony RM, Nimmerjahn F, Ashline DJ, Reinhold VN, Paulson JC, Ravetch JV. Recapitulation of IVIG anti-inflammatory activity with a recombinant IgG Fc. Science (2008) 320:373-6. doi:10.1126/science.1154315

78. Anthony RM, Kobayashi T, Wermeling F, Ravetch JV. Intravenous gammaglobulin suppresses inflammation through a novel $\mathrm{T}(\mathrm{H}) 2$ pathway. Nature (2011) 475:110-3. doi:10.1038/nature10134

79. Sondermann P, Pincetic A, Maamary J, Lammens K, Ravetch JV. General mechanism for modulating immunoglobulin effector function. Proc Natl Acad Sci U S A (2013) 110:9868-72. doi:10.1073/pnas.1307864110

80. Yu X, Vasiljevic S, Mitchell DA, Crispin M, Scanlan CN. Dissecting the molecular mechanism of IVIg therapy: the interaction between serum IgG and DC-SIGN is independent of antibody glycoform or Fc domain. J Mol Biol (2013) 425:1253-8. doi:10.1016/j.jmb.2013.02.006

81. Crispin M, Yu X, Bowden TA. Crystal structure of sialylated IgG Fc: implications for the mechanism of intravenous immunoglobulin therapy. Proc Natl Acad Sci U S A (2013) 110:E3544-6. doi:10.1073/pnas.1310657110

82. Ahmed AA, Giddens J, Pincetic A, Lomino JV, Ravetch JV, Wang L-X, et al. Structural characterization of anti-inflammatory immunoglobulin G Fc proteins. J Mol Biol (2014) 426:3166-79. doi:10.1016/j.jmb.2014.07.006

83. Campbell IK, Miescher S, Branch DR, Mott PJ, Lazarus AH, Han D, et al. Therapeutic effect of IVIG on inflammatory arthritis in mice is dependent on the Fc portion and independent of sialylation or basophils. J Immunol (2014) 192:5031-8. doi:10.4049/jimmunol.1301611

84. Leontyev D, Katsman Y, Ma X-Z, Miescher S, Käsermann F, Branch DR. Sialylation-independent mechanism involved in the amelioration of murine immune thrombocytopenia using intravenous gammaglobulin. Transfusion (2012) 52:1799-805. doi:10.1111/j.1537-2995.2011.03517.x

85. Guhr T, Bloem J, Derksen NIL, Wuhrer M, Koenderman AHL, Aalberse RC, et al. Enrichment of sialylated IgG by lectin fractionation does not enhance the efficacy of immunoglobulin $\mathrm{G}$ in a murine model of immune thrombocytopenia. PLoS One (2011) 6:e21246. doi:10.1371/journal.pone.0021246

86. Bayry J, Bansal K, Kazatchkine MD, Kaveri SV. DC-SIGN and alpha2,6sialylated IgG Fc interaction is dispensable for the anti-inflammatory activity of IVIg on human dendritic cells. Proc Natl Acad Sci U S A (2009) 106:E24; author reply E25. doi:10.1073/pnas.0900016106

87. Tjon ASW, van Gent R, Jaadar H, Martin van Hagen P, Mancham S, van der Laan LJW, et al. Intravenous immunoglobulin treatment in humans suppresses dendritic cell function via stimulation of IL-4 and IL-13 production. J Immunol (2014) 192:5625-34. doi:10.4049/jimmunol.1301260

88. Karsten CM, Pandey MK, Figge J, Kilchenstein R, Taylor PR, Rosas M, et al. Anti-inflammatory activity of IgG1 mediated by Fc galactosylation and association of FcyRIIB and dectin-1. Nat Med (2012) 18:1401-6. doi:10.1038/ $\mathrm{nm} .2862$

89. Thomann M, Reckermann K, Reusch D, Prasser J, Tejada ML. Fc-galactosylation modulates antibody-dependent cellular cytotoxicity of therapeutic antibodies. Mol Immunol (2016) 73:69-75. doi:10.1016/j. molimm.2016.03.002

90. Okazaki A, Shoji-Hosaka E, Nakamura K, Wakitani M, Uchida K, Kakita S, et al. Fucose depletion from human IgG1 oligosaccharide enhances binding enthalpy and association rate between IgG1 and FcgammaRIIIa. J Mol Biol (2004) 336:1239-49. doi:10.1016/j.jmb.2004.01.007

91. Colafrancesco S, Agmon-Levin N, Perricone C, Shoenfeld Y. Unraveling the soul of autoimmune diseases: pathogenesis, diagnosis and treatment adding dowels to the puzzle. Immunol Res (2013) 56:200-5. doi:10.1007/ s12026-013-8429-4

92. Jefferis R. Recombinant antibody therapeutics: the impact of glycosylation on mechanisms of action. Trends Pharmacol Sci (2009) 30:356-62. doi:10.1016/j.tips.2009.04.007

93. Trouw LA, Pickering MC, Blom AM. The complement system as a potential therapeutic target in rheumatic disease. Nat Rev Rheumatol (2017) 13:538-47. doi:10.1038/nrrheum.2017.125
94. Malhotra R, Wormald MR, Rudd PM, Fischer PB, Dwek RA, Sim RB. Glycosylation changes of IgG associated with rheumatoid arthritis can activate complement via the mannose-binding protein. Nat Med (1995) 1:237-43. doi:10.1038/nm0395-237

95. van de Geijn FE, de Man YA, Wuhrer M, Willemsen SP, Deelder AM, Hazes JMW, et al. Mannose-binding lectin does not explain the course and outcome of pregnancy in rheumatoid arthritis. Arthritis Res Ther (2011) 13:R10. doi:10.1186/ar3231

96. Nimmerjahn F, Anthony RM, Ravetch JV. Agalactosylated IgG antibodies depend on cellular Fc receptors for in vivo activity. Proc Natl Acad Sci U S A (2007) 104:8433-7. doi:10.1073/pnas.0702936104

97. Quast I, Keller CW, Maurer MA, Giddens JP, Tackenberg B, Wang LX, et al. Sialylation of IgG Fc domain impairs complement-dependent cytotoxicity. J Clin Invest (2015) 125:4160-70. doi:10.1172/JCI82695

98. Peschke B, Keller CW, Weber P, Quast I, Lünemann JD. Fc-galactosylation of human immunoglobulin gamma isotypes improves Clq binding and enhances complement-dependent cytotoxicity. Front Immunol (2017) 8:646. doi:10.3389/fimmu.2017.00646

99. Diebolder CA, Beurskens FJ, de Jong RN, Koning RI, Strumane K, Lindorfer MA, et al. Complement is activated by IgG hexamers assembled at the cell surface. Science (2014) 343:1260-3. doi:10.1126/science.1248943

100. Teeling JL, Mackus WJM, Wiegman LJJM, van den Brakel JHN, Beers SA, French RR, et al. The biological activity of human CD20 monoclonal antibodies is linked to unique epitopes on CD20. J Immunol (2006) 177:362-71. doi:10.4049/jimmunol.177.1.362

101. Kellner C, Derer S, Valerius T, Peipp M. Boosting ADCC and CDC activity by Fc engineering and evaluation of antibody effector functions. Methods (2014) 65:105-13. doi:10.1016/j.ymeth.2013.06.036

102. de Jong RN, Beurskens FJ, Verploegen S, Strumane K, van Kampen MD, Voorhorst $\mathrm{M}$, et al. A novel platform for the potentiation of therapeutic antibodies based on antigen-dependent formation of IgG hexamers at the cell surface. PLoS Biol (2016) 14:e1002344. doi:10.1371/journal.pbio.1002344

103. Schumaker VN, Calcott MA, Spiegelberg HL, Müller-Eberhard HJ. Ultracentifuge studies of the binding of IgG of different subclasses to the Clq subunit of the first component of complement. Biochemistry (1976) 15:5175-81. doi:10.1021/bi00668a035

104. Painter RH, Foster DB, Gardner B, Hughes-Jones NC. Functional affinity constants of subfragments of immunoglobulin G for Clq. Mol Immunol (1982) 19:127-31. doi:10.1016/0161-5890(82)90254-1

105. Sledge CR, Bing DH. Binding properties of the human complement protein Clq. J Biol Chem (1973) 248:2818-23.

106. Hughes-Jones NC. Functional affinity constants of the reaction between 125I-labelled C1q and C1q binders and their use in the measurement of plasma C1q concentrations. Immunology (1977) 32:191-8.

107. Malphettes L, Freyvert Y, Chang J, Liu P-Q, Chan E, Miller JC, et al. Highly efficient deletion of FUT8 in CHO cell lines using zinc-finger nucleases yields cells that produce completely nonfucosylated antibodies. Biotechnol Bioeng (2010) 106:774-83. doi:10.1002/bit.22751

108. Beck A, Reichert JM. Marketing approval of mogamulizumab: a triumph for glyco-engineering. MAbs (2012) 4:419-25. doi:10.4161/mabs.20996

Conflict of Interest Statement: Sanquin Research conducts Academic research in the field of immno- and hematology. It operates within "Stichting Sanquin Bloedvoorziening," a not for profit organization that manages the supply-chain of blood and blood products in the Netherlands. The authors declare no competing interests.

Copyright (c) 2018 Dekkers, Rispens and Vidarsson. This is an open-access article distributed under the terms of the Creative Commons Attribution License (CC BY). The use, distribution or reproduction in other forums is permitted, provided the original author(s) and the copyright owner are credited and that the original publication in this journal is cited, in accordance with accepted academic practice. No use, distribution or reproduction is permitted which does not comply with these terms. 